\title{
Mogens Lærke
}

\section{Interview med Pierre-François Moreau om den franske spinozisme og dens historie}

Pierre-François Moreau: Lektor ved Université de Paris IV-Sorbonne indtil 1992. Er i dag professor ved Ecole Normale Supérieure - Lettres et Sciences Humaines i Lyon. Han er leder af CERPHI (Centre d'études en rhétorique, philosophie et histoire des idées) og af GRS (Groupe de recherches spinozistes), som udgør en forskningsenhed under CNRS (Centre national de recherches scientifiques). Han har studeret filosofihistorien under Louis Althusser, Sylvian Zac og Alexandre Matheron og har udgivet adskillige værker om Spinoza (Spinoza, Editions du Seuil, 1975 ; L'Expérience et l'éternité, Presses Universitaires de France, Paris 1994 ; Spinoza et le spinozisme, coll. "Que sais-je ?", Presses universitaires de France, Paris 2003). Han har oversat Spinoza, senest en tosproget udgave af Tractatus Theologico-politicus, udgivet i samarbejde med Fokke Akkerman og Jacqueline Lagrée, og er redaktionschef for nyudgaven af Spinozas værker under forberedelse fra Presses universitaires de France. Har derudover udgivet værker om Lukretius, Hobbes, om utopibegrebet og er redaktør af en række antologier om receptionen af den antikke filosofi i klassikken.

Mogens Larke: Paul Vernière har betegnet Spinozareceptionen $i$ det 18. arbundredes Frankrig som "forvirringens ara". Blandt andet fordi Spinozas varker ikke genudgives og ikke er $i$ handlen, er han primart kendt gennem Pierre Bayles kommentar $i$ Dictionnaire historique et critique (1697, 2. udg. 1702), senere gennem Condillac (Essai sur l'origine des connaissances humaines (1746); Traité de systemes (1749)). Spinozismen reduceres ofte af oplysningstankerne til en slags radikal materialisme-f.eks. hos Diderot et La Mettrie. Hos andre - specielt tankerne indenfor prasteskabet - bliver Spinoza inkarnationen af det varst tankelige: Panteismen og fatalismen. Spinoza lases 
meget frit og på alle mulige måder. Er der elementer af det 18. årbundredes Spinozareception, som har overlevet opkomsten af filosofihistorien i Frankrig og, sammen med denne, den filologiske fordring om historisk og begrebslig troskab - med andre ord, er det muligt at finde nutidige arvtagere til det 18. årbundredes Spinoza?

Pierre-François Moreau: Jeg er ikke så sikker på, at den materialistiske tolkning af Spinoza, som man finder hos visse oplysningstænkere, er så reduktiv. Hvis det er tilfældet, betyder det, at materialismen allerede eksisterer på det pågældende tidspunkt og at man 'oversætter' Spinoza til denne allerede eksisterende doktrin. Men i virkeligheden er fænomenet mere komplekst: Læsningen af Spinoza er det, som tillader, at denne materialisme formuleres overhovedet og at den kan finde et nyt problemfelt adskilt fra den simple epikuræiske arv eller fra gentagelsen af Hobbes (eller fra en række hemmelige værkers angreb på kristendommen). For at sige det helt konkret: Hvis grundlæggelsen af materialismen $i$ en bestemt epoke består $i$ at opdage den nye figur, som den må antage for at tage sin tids videnskabelige fremskridt til efterretning, så er det 18. århunderedes materialisters problem at komme væk fra refleksionen over fysikken og tage livsvidenskaberne og de omvæltninger som disse kan give anledning til til efterretning. Det er for eksempel det, som Diderot gør i Le rêve de d'Alembert. Men det hænder, at denne reformulering af materialismen sker via det, som Vernière kalder 'neo-spinozisme'. Paradokset, om man så må sige, består $i$, at det er nødvendigt at modificere Spinozas tænkning for at den kan udgøre motoren i en sådan transformation. Men, når alt kommer til alt, kan man måske måle en tankes styrke ved de modifikationer, som den er i stand til at gennemløbe. Under alle omstændigheder er det mere interessant at afkode idéhistorien på denne måde frem for at reducere den til række misforståelser.

Denne materialistiske læsning af Spinoza, har den stadig sine arvtagere? Man kan formentlig finde dem i forbindelse med de moderne debatter om sjæl-legeme-problematikken. Men man finder også nogle indenfor samfundsvidenskaberne blandt de, som fastholder en kollektiv determinisme, som insisterer på at kritisere illusionen om subjektets autonomi. Materialismens nye figur består formentlig $i$ at tage humanvidenskabernes opdagelser til efterretning - og $\mathrm{i}$ bestræbelsen på at skabe de kategorier, som svarer til dem. Jeg vil insistere på det: Materialismen, det er ikke en doktrin, som er fastlagt én gang for alle. Det er langt snarere en position, som fornyes hele tiden i forhold til de konflikter, som opstår, når man vil afkode de konstitutive hændelser indenfor de praktiske videnskaber. Der er selvfølgelig visse temaer, som er til stede hele tiden, topö̈, som tillader at man kan placere sig, men der er intet mere idealistisk end at gentage en tidligere form for materialisme. De biologiske, ovenikøbet racistiske, materialismer fra slutningen af det 19. århunderede udgør et uhyggeligt eksempel. 
M. L.: De har selv skerevet et storre antal artikler om fortolkningen af spinozismen $i$ det 19. arrhundredes Frankrig, i sardeleshed hos de franske spiritualister (Victor Cousin, Emile Saisset, Louis Alexandre Foucher de Careil, etc.). L'Expérience et l'éternité indeholder også en kritik af Saissets fortolkning af Spinoza. Hvis de franske spiritualister $i$ dag primart er kendt for deres store redigeringsarbejder, var deres måde at lase Spinoza på ikeke desto mindre original, styret af deres eget spiritualistiske projekt og nedfaldet $i$ samtidige problematikeker. Hvordan er disse arbejder - som måske udgor den franske akademiske spinozismes vugge - stadig tilstede i den aktuelle franske spinozisme?

P.-F. M. : Vigtigheden af spiritualisterne fra Cousin-skolen er langt mere vidtrækkende end deres Spinozafortolkning: De er grundlæggerne af den franske filosofiske institution. Det gamle system var blevet ødelagt af Revolutionen. De har skabt et nyt og effektivt system, som er politisk struktureret og som formår at indarbejde impulser fra udlandet (den skotske skole ${ }^{1}$, den tyske idealisme), selv om de deformerer dem. Det er et system, som grundlægges på en genlæsning af Descartes som nationalfilosof, endog som nationalpsykolog (Discours de la méthode udgives uden de videnkabelige arbejder, hvortil den er en introduktion). Det er et system, som på én gang er teoretisk (Cousin har tilvejebragt fortolkningsskemaer for hele filosofihistorien med udgangspunkt i sin analyse af bevidstheden) og praktisk (det er det, som stadig eksisterer $\mathrm{i}$ det franske nationale uddannelsessystem, med filosofi på gymnasiet og et program, hvor filosofihistorien styres af den personlige tanke, men hvor omvendt denne sidste kun udtrykker sig inden for bestemte rammer). Det er i udgangspunktet et rigidt system, men dets funktion har tilladt større fleksibilitet og indarbejdningen af andre filosofiske retninger end den første spiritualismes eklektisme. Dette system fungerer stadig diskret i de anerkendte fortolkninger af Spinoza og kan genkendes på bestemte træk: På læsningen af Spinoza næsten udelukkende i forhold til Descartes (det er mest $\mathrm{i}$ udlandet, at man har udviklet sammenligningerne med Machiavelli og Hobbes); på uvidenheden om de kontekstuelle forhold (hvorimod den hollandske og italienske forskning har tilskrevet dem meget stor betydning); på forrangen givet til Etik og, måske i endnu højere grad, til Afhandling om forstandens forbedring (man anså denne tekst som en metodeteori, som kan adskilles fra resten af spinozismen), samt den vedvarende forglemmelse af de politiske tekster.

M. L.: I det forste bind af Spinoza (1968), angriber Martial Gueroult temmelig voldsomt den hegelianske lasning af Spinoza (og, på samme tid, de senere fortolkninger, som genoptager figurer fra denne). I Spinoza et le problème de l'expression (1968) prcesenterer Gilles Deleuze Spinoza som en slags anti-Hegel der, sammen med Nietzsche, modsatter sig den dialektiske tankeform (Spinoza, selvfolgelig, på forbaind). I sin bog om Spinoza og 
Hegel, Hegel ou Spinoza (1979), bestraber Pierre Macherey sig på at modstille deres respektive positioner $i$ et forsog på at undgå, at den ene stiller sig som dommer over den anden. Den franske spinozisme, fra Gueroult til Macherey, synes til tider at definere sig selv negativt i forhold til hegelianismen. Hvilke rolle spiller Hegel efter Deres mening $i$ den aktuelle franske spinozisme?

P.-F. M.: Man må tilskrive Hegel æren for i hvert fald én ting: At have bekræftet spinozismens vigtighed som filosofi, og ovenikøbet, på en bestemt måde, som selve betingelsen for den filosofiske tanke. De to indvendinger, som de franske spinozister har imod ham - de er i øvrigt forbundne med hinanden på kompleks vis -, angår spørgsmålet om attributterne og spørgsmålet om dialektikken. Den hegelianske fortolkning af attributterne som blotte 'synspunkter' på substansen er blevet genoptaget af mange Spinozafortolkere og har skabt en vedvarende mangel på forståelse af et problem, som i øvrigt er objektivt meget svært. Hvad angår dialektikken, har man indtryk af, at de franske spinozister svinger mellem to positioner: Enten betragter de dialektikken som en mystifikation og i dette tilfælde hylder de Spinoza for ikke at være faldet $\mathrm{i}$ denne fælde. Eller også anser de den sande dialektik som den kritiske tankes uomtvistelige figur, men fastholder, at Hegel har givet den en falsk, idealistisk fortolkning, og at det er hos Spinoza, at man skal lede efter fundamentet for den rigtige fortolkning. Denne sidste mulighed er den mest forførende, men man fortæller os aldrig, hvordan man kan realisere det løfte, den indeholder. Efter min mening er det Althusser, som er kommet nærmest, men han citerer stort set ikke Spinoza i sine to fundamentale artikler om den materialistiske dialektik, genoptaget i Pour Marx.

M. L.: I en anmeldelse af Martial Gueroults store vark om Spinoza karakteriserer Gilles Delenze Gueroults arbejde som begyndelsen på den videnskabelige fortolkning af Spinoza. Man kunne her tilfoje Alexandre Matherons Individu et communauté chez Spinoza, ligeledes udgivet $i$ slutningen af tresserne. Det er et faktum, at siden deres udgivelse er Gueroults og Matherons arbejder forblevet de referencevarker som en fransk laser af Spinoza er mere eller mindre forpligtet til at forbolde sig til. Men kan De vare enig med Deleuze på dette punkt? Er der en fransk spinozisme, som man kan kvalificere som 'videnskabelig' for disse to forfattere (jeg tanker her pa kommentatorer som Victor Delbos eller Léon Brunschvicg)? Og, efter Deres mening, bvilken indflydelse har Gueroults og Matherons arbejder haft på fortolkningen af Spinoza i Frankrig?

P.-F. M.: Den sande grundlægger af den videnskabelige læsning af Spinoza i Frankrig, det er Delbos, og Gueroult har altid anerkendt det. Jeg taler her om 
afhandlingen om Spinoza og om problemet om moralen. Brunschvicg har spillet en mere besværlig rolle: Han har forsvaret en rationalisme, som lagde vægten på fornuften $\mathrm{i}$ den matematiske tanke - og i forhold til alle irrationalismerne, som udviklede sig i Frankrig i begyndelsen af det tyvende århunderede, er det allerede ikke så skidt endda. Men hans læsning af Spinoza er "cartesianiserende" følgende den tradition, som jeg talte om lige før, og endvidere føjer den intet til den egentlige forståelse af Spinoza. Der er et tomrum på omkring trekvart århundrede i Spinoza-studierne - med enkelte undtagelser (jeg tænker her på Jean-Toussaint Desantis desværre uafsluttede værk).

Man må nævne fire navne i forbindelse med fornyelsen i tresserne: Gueroult, Zac, Deleuze, Matheron.

Det er Sylvain Zac, der som den første har taget Spinoza alvorligt, også i forhold til felter (livet, Skriften), som ikke tidligere havde tilbageholdt opmærksomheden i den franske forskning. Han har vurderet, at udviklingen af disse spørgsmål hos Spinoza havde udgangspunkt i en stram begrebslig analyse, at de fortjente tekstforklaringer og arkitektoniske optegnelser, således som den franske filosofihistoriske skole var i stand til at gøre det for de andre filosoffer. Han har desuden, efterfølgende, taget spinozismens idéhistorie op (i særdeleshed om panteisme-striden) ${ }^{2}$, hvilket ikke var almindeligt i Frankrig på det tidspunkt.

Gueroult har markeret forskningen definitivt og indskrevet de spinozistiske studier i forhold til en streng tilbagevenden til teksterne, insisteret på rekonstruktionen af den præcise betydning af begreber og på afvisningen af alt det, man kunne kalde for historiografisk amatørisme. Siden ham er det umuligt, når man hos Spinoza finder ordene "substans", "idé" eller "forestillingsevne", at forudsætte, at man allerede ved, hvad det vil sige, fordi man også finder dem hos de andre filosoffer eller simpelthen i dagligdagssproget - nej, det er selve det spinozistiske systems struktur, som giver dem betydning, og det samme ord hos Descartes, Spinoza og Leibniz kan have tre forskellige betydninger inden for de tre intellektuelle universer, som tilskriver dem deres mening. Dette udelukker naturligvis ikke, at systemerne sammenlignes, og heller ikke at deres termer og problematikker har noget til fælles - men det må bevises og ikke forudsættes. Denne fordring om stringens er et definitivt fremskridt, som Martial Gueroult har æren for, også selv om man ikke er enig i denne eller hin af hans fortolkninger (f.eks. er der i dag ingen som forsvarer hans hypotese om "substanser med et enkelt attribut") eller man har en anden idé om, hvad som udgør en filosofis systematicitet (man kan forsøge at konstruere modeller for systematiciteten, som giver mere plads til konteksten, til traditionerne, til disputterne, og til filosoffens intellektuelle biografi - en dynamisk systematicitet, endog 'dialektisk' hvis man vil bruge dette ord igen!). 
Deleuze har foreslået en slags "nietzscheansk" fortolkning eller, mere præcist, en fortolkning centreret omkring Spinozas afvisning af negativiteten. Selv for de, som ikke delte Deleuzes mening, havde hans fortolkning en uomtvistelig styrke og den har i høj grad bidraget til at trække Spinoza bort fra de lidt støvede akademiske fortolkninger.

I Matherons første arbejder forekommer det, at han følger Gueroult strengt: Man havde lidt det indtryk, at han udviklede læsningen af de politiske aspekter, som ikke interesserede Gueroult. Siden da er man blevet klar over, at han havde en ekstraordinært stærk fortolkningsevne og at han, uden at være utro mod de positive sider af Gueroults metode, var i stand til at have overblik over hele Spinozas tanke, dens ærinde og dens udvikling - og i særdeleshed var han i stand til at give en filosofisk og ikke anekdotisk forklaring på denne udvikling. Det er beklageligt, at han endnu ikke har udgivet de store arbejder, som han har lovet os om Afhandling om forstandens forbedring og om kraftens ontologi. Gennem det, som vi kender fra hans artikler og hans seminarer, bliver det et virkelig nyt og sammenfattende bidrag. De fleste af de nutidige franske forskere (og ikke blot franske) er mærkede af hans arbejde - også selv om de i øvrigt kan være inspirerede af de store tyske arbejder (Walther eller Bartuschat), italienske (Giancotti eller Mignini), hollandske (Hubbeling eller Akkerman), eller amerikanske (Curley eller Rice).

M. L.: Man taler til tider om en "ny Spinoza" i Frankrig (Warren Montag): En engageret spinozisme tat knyttet til den nutidige politiske filosofi, reprasenteret af, for eksempel, Etienne Balibar eller Antonio Negri (Gilles Deleuze forbliver her en undtagelse, som er svar at kategorisere). Indtil bvilket punkt er det tilladt her at tale om en spinozistisk "tendens" adskilt fra den mere "akademiske" spinozisme? Og indtil bvilket punkt - og det ville her vare nodvendigt at adskille de forskellige tilgange til Spinoza i denne lejr - er disse fortolkninger for 'interesserede' til at kunne blive anvendt af de mere universitare spinozister?

P.-F. M. Man skal passe på med at påhægte Antonio Negri: Han har skrevet sin bog på italiensk, i et italiensk fængsel. Hans fremgangsmåde skylder endvidere hans nationale tradition meget (også selv om han er meget påvirket af franskmændene og omvendt, at han har påvirket dem. Hans bog og diskussionen omkring den udgør et virkelig godt eksempel på den aktuelle internationalisering af forskningen), som den også skylder hans filosofiske og politiske interesser meget. Hvad angår forbindelserne mellem de politisk engagerede studier og de universitære studier, er de strengt nødvendige: Et arbejde inspireret af et socialt engagement, men som ikke støtter sig på den seneste forskning, mister ethvert solidt grundlag og risikerer at reducere sig selv til den blotte gentagelse af den gode vilje. Og jeg kan ikke se hvilken grund der skulle være 
til af afvise at anvende forslag fra en forskning under påskud af, at den har et ærinde. Forskningen har det i øvrigt altid, blot anderkender den dem eller ej.

M. L.: I forbold til denne "nye Spinoza" fremmaner man ofte navnet Louis Althusser for at forklare dens opkomst. Men, når alt kommer til alt, så er Althussers tekster om Spinoza ganske fä og hans bemarkninger om spinozismen spredte. Efter Deres mening, bvilken rolle spiller Althusser i de nutidige studier i spinozismen?

P.-F. M.: Althusser har skrevet meget lidt om Spinoza, men den spinozistiske fremgangsmåde er til stede overalt i hans tænkning og, hver gang han taler om ham, så påpeger han et afgørende teoretisk felt, selv om han ikke gør det i et teknisk sprog. Men selv det, han siger om andre tematikker, forudsætter en spinozistisk begrebslighed og påpeger underforstået ubemærkede spørgsmål, som man kan stille til Spinoza. På en måde svarer hele hans begrebsliggørelse af filosofihistorien som en konfliktuel historie til den spinozistiske måde at udøve denne historie på. For eksempel: Når Spinoza i et brev til Hugo Boxel stiller Platon og Aristoteles voldsomt op imod Demokrit og Epikur, så refererer han ikke til disse doktriners indhold (når alt kommet til alt, så er han selv overhovedet ikke atomist, og hans erkendelsesteori skylder stort set intet til teorien om simulakrer), men han konfronterer positioner ${ }^{3}$. Det var præcis det, som Althusser gjorde.

M. L.: De sidste ärtiers franske udgivelser om Spinoza, har jeg indtryk af, er ofte karakteriseret ved en vilje til til at reevaluere visse begreber, som tidligere er blevet anset som meget lidt vigtige hos Spinoza. Säledes Michèle Bertrands arbejde om begrebet om "imaginationen" hos Spinoza; diverse studier i begrebet om "sprog" hos Spinoza; og, hos Dem selv, de udviklede analyser af begrebet "erfaring" eller begrebet "historie", som man finder $i$ l'Expérience et l'éternité. For nylig har Lorenzo Vinciguerra skerevet en afhandling om Spinozas tegnbegreb. Hvordan skal man forstå denne slags analyser? Kan man tale om en 'stromning' i Spinozafortolkningen eller er disse tilgange for forskellige til at kunne falde ind under den samme kategori? Kan man anse dem som diskrete aktualiseringer af den spinozistiske filosofi og derfor styrede af den nutidige filosofis problematikeker? Eller drejer det sig simpelthen om nye resultater, som tilfojer sig akekumulativt til de sidste airtiers videnskabelige fortolkningsarbejder?

P.-F. M: Udforskningen af tidligere oversete begreber forholder sig til det nødvendige arbejde, som består $\mathrm{i}$ at løsrive sig fra gamle problematikker, specielt fra de, som "cartesianiserede" Spinoza eller som ville gøre ham til en slags spiritualist, der fornægtede erfaringen, sproget eller forestillingsevnen. Det skal her siges i forbifarten, at Descartes selv har været offer for denne slags tra- 
vesteringer og at man kun er begyndt på at frigøre ham fra dem. Det er klart, at det ofte er den vægt, som den nutidige filosofi (eller "humanvidenskab") lægger på bestemte problemer, som i udgangspunktet tillader, at man bliver opmærksom på hvilke begreber, som er blevet overset i de klassiske studier af filosofien. Derefter må den præcise læsning af teksterne, rekonstitutionen af måden at stille spørgsmål på og den intellektuelle fremgangsmåde spille deres rolle for at undgå, at læseren blot "oversætter". At læse Freud kan hjælpe os til at stille nye spørgsmål til Spinoza, men hvis man når frem til simpelthen at tro, at han siger det samme som Freud, så lærer det os intet nyt om hverken den ene eller den anden. Det er mere nyttigt for eksempel at skelne mere præcist det, som adskiller dem på det sted, hvor de er tættest på hinanden. Det er sandt, at Etiks tredje del i dag får os til at tænke på bestemte psykoanalytiske overvejelser, men imaginationens mekanismer dækker ikke over det ubevidste. Det er instruktivt at spørge sig selv om, hvad det er, som begrunder denne fornemmelse af bekendthed og hvilke grænser, der er for den. Som altid (og som Freud i øvrigt sagde det, om end ikke på denne måde) er det grænserne, som giver forståelsen af strukturen. En anden nyhed, som er værd at bemærke i de franske arbejder (eller arbejder af udlændinge, som forsvarer afhandlinger i Frankrig) er en fornyet interesse for videnskabshistorien. Dette koblingspunkt mellem filosofihistorien og videnskabshistorien har i lang tid været meget karakteristisk for den franske universitære institution, men den havde ikke længere nogen effekter i Spinozastudierne. Denne produktive fremgangsmåde genoptages for øjeblikket, med arbejderne, færdige eller undervejs, om matematikken, fysikken, livsvidenskaberne, grammatikken.

M. L.: Til slut et kort sporgsmål. Konferencen for nylig $i$ Cerisy-La Salle blev arrangeret, har jeg indtryk af, for at lave en slags opgorelse over spinozismens situation $i$ Frankrig $i$ dag ${ }^{4}$. Den gav indtryk af et temmeligt spredt forskningsfelt, ikeke sandt? Under alle omstcondigheder, de teoretiske stromninger, som styrer Spinozastudierne, synes $i$ dag at vare svarere at definere end for, lad os sige tyve eller tredive air siden. Hvilken fremtid er der for spinozismen $i$ Frankrig $i$ dag, efter Deres mening? Kan De udpege bestemte stromninger eller tendenser?

P.-F. M. I forste omgang er der et punkt, som er fælles for hovedparten af de aktuelle franske studier: Det er, at de støtter sig på en fælles forståelse af den filosofiske rationalitet, af den interne læsning af teksterne, eventuelt for at konfrontere dem med andre tekster. Man må glæde sig over denne stringens, over denne omsorg for begrebet, men man må beklage, at den ikke allierer sig, i hvert fald ikke nok, med en virkelig kontekstuel interesse: Det er ikke i Frankrig i dag, at der produceres arbejder om det intellektuelle klima i Hol- 
land, om konflikterne i de portugisiske jøders fællesskab. Eller snarere eksisterer sådanne studier, men de udmunder ikke umiddelbart i en fornyelse af Spinozaforskningen.

I anden omgang kan jeg konstatere en større filologisk samvittighed, også selv om de franske filosoffer generelt ikke er filologer. Der er ingen i dag som kunne komme på den tanke kun at citere Spinoza på fransk uden også at henvise til den latinske tekst. Oversættelsen af Meinsmas bog, af Kolakowskis, kendskabet til Akkermans, Steenbakkers og Proiettis arbejder gør, at de franske Spinozaforskere, også selv om det ikke er deres primære interesse, er mere bevidste end tidligere om problemer angående det miljø, det sprog eller den kultur, hvori en filosofi udvikler sig.

Sidst har de de franske forskere forstået (og de er ikke de eneste), at de må dele deres spørgsmål og deres resultater med forskere fra andre lande. Udviklingen i bibliografierne de seneste år er ganske talende på dette punkt. Sigende er ligeledes det faktum at, i Cerisy sidste sommer, var der tyskere, italienere, brasilianere, israelere, marokkanere, tunesiere, kamerunesere. Og danskere!

\section{Litteraturliste}

Akkerman, Fokke: (1977) Spinoza's tekort aan woorden: Humanistische aspecten van zijn schriverschap, Leiden.

Akkerman, Fokke: (1980) Studies in the posthumous works of Spinoza: On style, earliest translation and reception, earliest and modern edition of some texts, Meppel.

Althusser, Louis: (1980) Pour Marx, Paris.

Althusser, Louis: (1994) Appendiks in L'avénir dure longtemps, Paris, pp. 467-87.

Balibar, Etienne: (1985) Spinoza et la politique, Paris.

Bartuschat, Wolfgang: (1992) Spinozas Theorie des Menschen, Hamburg.

Bayle, Pierre: (1697, 2 udg. 1702) Dictionnaire histoirique et critique, Rotterdam.

Bertrand, Michèle: (1984) Spinoza et l'imaginaire, Paris.

Brunschvicg, Léon: (1923) Spinoza et ses contemporains, Paris.

Condillac, Etienne Bonnot de: (1746) Essai sur l'origine des connaissances humaines.

Condillac, Etienne Bonnot de: (1649) Traité de systèmes.

Curley, Edwin: (1969) Spinoza's Metaphysics: An essay in interpretation, Cambridge.

Curley, Edwin: (1988) Bebind the geometrical method: A reading of Spinoza's 'Ethics", Princeton.

Delbos,Victor: ([1896] 1990) Le problème du mal dans la philosophie de Spinoza, Groupe de recherches spinozistes, Textes et documents nr. 3, Paris.

Deleuze, Gilles: (1968) Spinoza et le problème de l'expression, Paris.

Deleuze, Gilles: (1970. 2. udg.1981) Spinoza: philosophie pratique, Paris.

Desanti, Jean-Toussaint: (1956) Introduction à l'bistoire de la philosophie, Paris

Diderot, Dénis: ([1769] 1951) Le Rêve de d'Alembert, red. Paul Vernière, Paris.

Foucher de Careil, Louis Alexandre: (1862) Leibniz, Descartes et Spinoza, Paris.

Giancotti, Emilia: (1969) Ricerche lessicali su opere di Descartes e Spinoza, Rom.

Giancotti, Emilia: (1970) Lexicon Spinozanum, Den Haag. 
Gueroult, Martial: (1968) Spinoza. Dieu, Paris.

Gueroult, Martial: (1974) Spinoza. L'âme, Paris.

Hubbeling, Hubertus G.: (1964) Spinoza's Methodology, Assen.

Hubbeling, Hubertus G: (1978) Spinoza, München.

Jacobi, Friedrich Heinrich: (1785) Ueber die Lehre des Spinoza in Briefen an den Hernn Moses Mendelssohn.

Kolakowski, Leszek: (1969) Chretiens sans Eglise. La conscience religieuse et le lien confessionnel au XVIIe siècle, overs. Anna Posner, Paris.

Macherey, Pierre: (1979) Hegel ou Spinoza, Paris.

Matheron, Alexandre: (1969) Individu et communauté chez. Spinoza, Paris.

Matheron, Alexandre: (1971) Le Christ et le salut des ignorants chez. Spinoza, Paris.

Mendelssohn, Moses: (1755) Philosophische Gespräche.

Meinsma,, Konraad Oege: (1896) Spinoza en zijn Kring, 'S-Gravenhage.

Meinsma, Konraad Oege: (1983) Spinoza et son cercle, overs. S. Roosenburg, Paris.

Mignini, Fillippo: (1981) Ars imaginandi: apparenza e rappresentazione in Spinoza, Napoli.

Mignini, Fillippo (red.): (1986) Spinoza: Korte verhandeling van God, de mensch en deszelvs welstand, L'Aquila.

Mignini, Fillippo: (1990) Dio, l'uomo, la liberta: studi sul "Breve trattato" di Spinoza, L'Aquila.

Mignini, Fillippo: (2000) L'etica di Spinoza: introduzione alla lettura, Roma.

Montag, Warren (red.): (1997) The New Spinoza, Minneapolis / London.

Moreau, Pierre-François (1994): L'expérience et l'éternité, Paris.

Negri, Antonio (1981): L'Anomalia selvaggia: saggio su potere e potenza in Baruch Spinoza, Milano.

Proietti, Omero: (1983) "Sul problema di un assioma inutile in Spinoza", in Rivista di filosofia neo-scolastica, nr. 75, pp. 223-242.

Proietti, Omero: (1985) “Adulescens luxu perditus: classici latini nell'opera di Spinoza”, in Rivista Filosofia neo-scolastica, nr. 2, pp. 210-257.

Rice, Lee C.: (1971) "Spinoza on individuation", in The Monist, nr. 55, pp. 640-659.

Rice, Lee C.: (1977) "Emotion, appetition and conatus in Spinoza", in Revue internationale de philosophie, nr. 31, pp. 101-116.

Rice, Lee C.: (1985) "Spinoza's account of sexuality", in Philosophy Research Archives, nr. 10, pp. 19-34.

Rice, Lee C.: (1985) "Spinoza, Bennett, and teleology", in The Southern Journal of Philosophy, nr. 23/2, pp. 241-253.

Saisset, Emile (red.): (1842) Spinoza. Oeuvres, Paris.

Saisset, Emile: (1860) Introduction critique aux oeuvres de Spinoza, Paris.

Saisset, Emile: (1862) Précurseurs et disciples de Descartes, Paris.

Steenbakkers, Piet: (1988) Opera minora van Spinoza: Een bespreking en aantekeningen, Amsterdam.

Steenbakkers, Piet: (1994) Spinozas "Ethica" from manuscript to print: Studies on text, form and related topics, Assen.

Vernière, Paul: (1954) Spinoz̧a et la pensée française avant la Révolution, Paris.

Walther, Manfred: (1971) Metaphysik als Anti-Theologie, Hamburg.

Walther, Manfred: (1996) Das Leben Spinozas: Eine Bibliographie, Hannover.

Zac, Sylvain: (1965) Spinoza et l'interprétation de l'Ecriture, Paris.

Zac, Sylvian: (1989) Spinoza en Allemagne. Mendelssohn, Lessing et Jacobi, Paris. 


\begin{abstract}
Noter
${ }^{1}$ Skotsk filosofisk bevægelse i det 19. århundrede, som udspringer fra en kritik af Humes radikale empirisme, en "moderat" empirisme, som afviser skepticismen, også kaldt common sense filosofi. Primære repræsentanter : Thomas Reid, Dugalt Steward, William Hamilton. Inspirationskilde i Frankrig for Victor Cousin, jf. V. Cousin, "La philosophie écossaise", seminar fra 1819, publiceret i 1845. O.a.

${ }^{2}$ Der henvises til de ophedede diskussioner mellem Jacobi og Mendelssohn omkring spørgsmålet om Lessings formodede spinozisme i sidste halvdel af det 19. århundrede. O.a.

${ }^{3}$ Jf. brev fra Spinoza til Hugo Boxel, Ep. LVI. O.a.

${ }^{4}$ Konferencen Spinoza aujourd'hui blev holdt i Cerisy La Salle, Normandiet, i juli 2002.
\end{abstract}

